\title{
HUBUNGAN KECERDASAN EMOSIONAL DENGAN KEPUASAN KERJA GURU SEKOLAH MENENGAH ATAS DI KOTA KUPANG
}

\author{
Delsylia Tresnawaty Ufi ${ }^{1}$ \\ Institut Agama Kristen Negeri Kupang \\ delsyufi@gmail.com \\ Sutarto Wijono ${ }^{2}$ \\ Universitas Kristen Satya Wacana Kupang \\ sutartown@yahoo.com
}

\begin{abstract}
This research examines the relationship between emotional intelligence and the satisfaction of teachers work in the Senior high school in Kupang. The populations in this study were 419 teachers and the sample taken consisted of 106 teachers from the determined contributions. Wong and the Law Emotional Intelligence Scale (WLEIS, 2002) were used to assess emotional intelligence, and the overall job satisfaction developed by Dhespande (1996) was used to assess job satisfaction. The validity of instruments is measured by the total correlation of corrected items while reliability is measured using the Cronbach Alpha technique. The instruments used in this research are valid and reliable. The data analysis techniques used are correlation analysis. The results showed that there was a significant link between emotional intelligence, and three aspects of emotional intelligence with work satisfaction $(P<0,05)$.

Keyword: Emotional intelligence, Work Satisfaction.
\end{abstract}

\begin{abstract}
Abstrak
Penelitian ini meneliti hubungan antara kecerdasan emosi, dan kepuasan kerja guru di SMA Negeri di kota Kupang. Populasi penelitian 419 guru dan sampel dalam penelitian ini terdiri dari 106 guru. Wong dan Law Emotional Intelligence Scale (WLEIS, 2002) digunakan untuk menilai kecerdasan emosi, dan Overall Job Satisfaction dikembangkan oleh Dhespande (1996) digunakan untuk menilai Kepuasan Kerja. Validitas instrumen diukur dengan korelasi total item yang dikoreksi sedangkan reliabilitas diukur menggunakan teknik alpha Cronbach. Instrumen yang digunakan dalam penelitian ini valid dan dapat diandalkan. Teknik analisis yang digunakan adalah analisis korelasi. Hasil penelitian menjelaskan bahwa ada hubungan yang signifikan antara kecerdasan emosional, dan tiga aspek kecerdasan emosional dengan kepuasan kerja $(\mathrm{p}<0,05)$.

Kata kunci: Kecerdasan emosional, kepuasan kerja.
\end{abstract}




\section{PENDAHULUAN}

Sekolah dapat menunjukkan kinerja yang baik, jika kepuasan kerja Guru tidak diabaikan (Ngimbudzi, 2009). Kepuasan kerja guru berdampak pada pencapaian kualitas pendidikan itu sendiri. Kualitas pendidikan dihasilkan dari efektifitas mengajar Guru dan kinerja guru yang baik yang disebabkan kepuasan kerja dari Guru itu sendiri. Sebagaimana penelitian dari Schneider (2003) bahwa kepuasan kerja Guru berpengaruh pada kinerja Guru dan efektifitas mengajar. Selanjutnya, kepuasan kerja Guru berpengaruh terhadap bagaimana Guru berperilaku di sekolah dalam menciptakan suasana pendidikan, menumbuhkan percaya diri, lebih mendorong perhatian pada kemajuan siswa dan memperkuat kesehatan mental guru dalam menangani permasalahan yang dihadapi oleh siswa (Sisask, 2014). Oleh karena itu, sehat tidaknya lembaga pendidikan salah satunya ditentukan oleh Guru (Rochaety et al, 2006). Menurut data Organisasi Pendidikan, Ilmu Pengetahuan, dan Kebudayaan Perserikatan Bangsa Bangsa (UNESCO) tahun 2012 melaporkan Indonesia berada di peringkat ke- 64 dari 120 negara berdasarkan penilaian Education Development Index (EDI) atau Indeks Pembangunan Pendidikan. Sementara itu, The United Nations Development Programme (UNDP) melaporkan Human Development Index (HDI) Indonesia mengalami penurunan dari peringkat 108 pada 2010 menjadi peringkat 124 dari 180 negara pada tahun 2012. Pada 14 Maret 2013 dilaporkan urutan 121 dari 185 negara. Hal tersebut terjadi karena tenaga pendidik yang mengeluhkan kesejahteraan mereka kurang terpenuhi, sehingga berdampak pada kinerja mereka dan pada akhirnya terjadi penurunan mutu pendidikan Indonesia. Selanjutnya disebutkan bahwa hal ini disebabkan oleh gaji tenaga pendidik di Indonesia yang masih terhitung rendah berdasarkan survey dari World Bank yang melibatkan sedikitnya 12 negara di Asia (Dellasera, dalam Kompasiana, 2013).

Ada beberapa fenomena yang nampak terkait dengan kepuasan kerja berdasarkan hasil observasi dan wawancara dengan beberapa guru pada tanggal 19 Januari 2014. Secara positif, pada tahun 2013 pembayaran tunjangan profesi guru di Kota Kupang sesuai dengan aturan dan waktu yang ditetapkan, sehingga tidak ada lagi keluhan karena keterlambatan pembayaran tunjangan guru dibanding tahun-tahun sebelumnya. Selain itu, terdapat pengawasan yang baik dari atasan terhadap bawahan dan hubungan dengan rekan guru pun terjalin dengan baik, hal ini nampak ketika memasuki jam sekolah dan hendak pulang saling bertegur sapa satu sama lain.

Di sisi lain, guru masih mengalami hal yang bersifat negatif. Salah satu contoh guru mengalami ketidakpuasan kerja ditandai oleh adanya Guru Republik Indonesia yang mengeluhkan 
pelaksanaan pembayaran tunjangan guru yang sering bermasalah. Komunitas Guru Jawa Barat yang merupakan gabungan guru dari beberapa organisasi guru, melaporkan tidak utuhnya pembayaran tunjangan profesi guru di Jawa Barat ( Napitupulu dalam Kompas, 2012). Selain itu, di beberapa sekolah SMP Kota Pematangsiantar adanya ketidakpuasan oleh guru terhadap kepala sekolah yang kurang menghargai guru saat melaksanakan tugas tambahan seperti pembinaan senam pagi, pembinaan petugas upacara bendera, pemberian upah pembinaan ekstrakurikuler yang tidak sepadan dengan lelah pembina, mengkritik pekerjaan guru yang mengakibatkan guru tidak melaksanakan pekerjaannya dengan sepenuh hati (Hutagaol, 2012). Selanjutnya, data dari UPT Pengembangan Pendidikan Formal dan non formal Provinsi NTT (2009, November 4), bahwa masih ada guru yang mengeluh karena mengajar di desa-desa lebih dari satu mata pelajaran sehingga mempengaruhi kesejahteraannya dan juga mutu pendidikan. Di samping itu, di lingkungan Sekolah Menengah Atas Kota Kupang (2014) terdapat guru yang mengeluh karena mengajar mata pelajaran yang bukan bagian keahliannya, keluhan lainnya menyangkut pengawas yang jam tugasnya dinilai tidak sebanyak jam mengajar guru tetapi juga mendapat tunjangan, juga keluhan dari beberapa guru yang mengatakan atasan belum melaksanakan tugasnya secara baik, selanjutnya promosi jabatan yang tidak adil di mana ada guru yang sudah bekerja bertahun-tahun tidak pernah mendapat kesempatan maju dalam organisasi sekolah, berikutnya ketidakhadiran guru saat mengajar di kelas, jauhnya lokasi sekolah dari tempat tinggal guru, dan jumlah beban kerja yang melebihi jam kerja. Sikap-sikap mengeluh dan ketidakhadiran guru dapat berpengaruh pada kualitas pendidikan itu sendiri (Michaelowa, 2002). Hal tersebut sejalan dengan Zembylas dan Papanastasiou (2004), bahwa faktor utama ketidakpuasan kerja disebabkan oleh kelebihan beban kerja dan upah yang rendah. Selanjutnya Feber (dalam Agyekum, Suapim dan Peprah, 2013) mengatakan bahwa ketidakpuasan guru juga pada akhirnya mengurangi kemampuan untuk memenuhi kebutuhan siswa dan berdampak signifikan pada gangguan psikologis yang mengarah ke peningkatan ketidakhadiran, dan cacat tingkat tinggi yang terkait dengan stress.

Berdasarkan fenomena-fenomena di atas, dapat dikatakan bahwa guru mengalami ketidakpuasannya dalam bekerja dapat berpengaruh pada kualitas pendidikan itu sendiri. Sebab guru yang merasa tidak puas mempengaruhi proses belajar siswa dan pertumbuhan akademis mereka (Gehlawat, 2012). Selain itu, ketidakpuasan berdampak pada ketidakhadiran dan keluarnya tenaga kerja. Sebagaimana yang dikatakan oleh Robbins (dalam Munandar, 2001), ketidakpuasan kerja pada tenaga kerja diungkapkan ke dalam berbagai macam cara seperti, 
meninggalkan pekerjaan, selalu mengeluh, membangkang, serta menghindari sebagian tanggung jawab mereka.

Hal di atas, didukung dengan hasil penelitian dari Latham (dalam Ngimbudzi, 2009) bahwa kepuasan kerja guru berhubungan dengan aspek ekstrinsik yang meliputi gaji dan keamanan kerja. Dengan kata lain, pentingnya kepuasan kerja guru yang tinggi menunjukkan akan kualitas dan kompetensi guru dalam memajukan masa depan pendidikan, kesetaraan dan pencapaian cita-cita para siswa dan demi mencapai keberhasilan dan kualitas pendidikan itu sendiri (Gehlawat, 2012). Oleh karena itu, untuk mencapai tujuan organisasi pendidikan yang berkualitas tentunya dipengaruhi oleh kepuasan kerja guru. Hal ini didukung dengan penelitian dari Michaelowa (2002) bahwa kualitas pendidikan dipengaruhi oleh kepuasan kerja guru. Sebab penelitian terbaru pada negara-negara berkembang menggarisbawahi fakta bahwa lebih dari satu seperempat dari guru meninggalkan tugas mengajar yang dilakukannya karena ketidakpuasan kerja (Henke, dalam Agyekum, 2013). Hal ini sejalan dengan Clark, Georgellis dan Sanfey (dalam Chao, 2011) bahwa kepuasan kerja yang rendah berdampak pada pemberhentian dari kerja tingkat tinggi. Selain itu juga rendahnya kepuasan kerja berpengaruh pada perilaku absen guru (Michaelowa, 2002).

Guru sebagai elemen yang penting dalam meningkatkan sumber daya manusia yang berkualitas dan berguna bagi intelektual bangsa.Dalam kaitannya dengan guru, maka kepuasan kerja guru menurut Lawer (dalam Agyekum et al., 2012) bahwa konsep kepuasan guru merujuk kepada sebuah hubungan afektif guru dengan peranan pengajarannya. Selanjutnya, kepuasan guru merupakan sebuah fungsi dari hubungan yang dirasakan antara apa yang seseorang inginkan dari pengajaran dan apa yang dirasakan itu yang ditawarkan kepada guru. Dengan demikian Locke (dalam Luthans, 2006) menjelaskan kepuasan kerja meliputi reaksi atau sikap kognitif, afektif, dan evaluatif yang menyatakan bahwa keadaan emosional yang menyenangkan atau positif yang dihasilkan dari penilaian kerja dan pengalaman kerja seseorang

Kepuasan kerja guru menjadi penting dalam setiap jenjang pendidikan. Secara khusus bagi Sekolah Menengah Atas, karena guru yang puas dengan pekerjaan mereka dapat meningkatkan produktivitasnya dalam hal mempersiapkan siswa masuk ke dunia Perguruan Tinggi. Hal ini sejalan dengan tujuan dari pendidikan menengah yang dimuat dalam peraturan pemerintah RI Nomor 29 tahun 1990 tentang pendidikan menengah. Dalam peraturan itu, tujuan pendidikan menengah disebutkan untuk: (pada pasal 2-3), yakni meningkatkan pengetahuan untuk melanjutkan pendidikan ke jenjang yang lebih tinggi, mengembangkan diri sejalan dengan pengembangan ilmu, teknologi, dan kesenian; meningkatkan kemampuan sebagai anggota 
masyarakat dalam melakukan hubungan timbal balik dengan lingkungan sosial, budaya dan alam sekitarnya (Pidarta, 2000). Dengan demikian untuk mencapai tujuan pendidikan menengah ini, maka guru harus dapat menjalankan tugas-tugas pokoknya dengan baik, termasuk pada Sekolah Menengah Atas di kota Kupang.

Hal tersebut di atas mendorong penulis untuk melakukan penelitian mengenai kepuasan kerja dalam dunia pendidikan, khususnya pendidikan pada Sekolah Menengah Atas Negeri di kota Kupang. Selain itu, ada beberapa pertimbangan lain yang melandasi mengapa penulis memilih guru Sekolah Menengah Atas Negeri di kota Kupang. Sebagai objek penelitian, beberapa pertimbangan tersebut di antaranya adalah guru sebagai pendidik bertanggungjawab penuh dalam mempersiapkan siswa untuk melanjutkan pendidikan ke jenjang yang lebih tinggi. Selain itu, guru dapat mempersiapkan siswa untuk mengembangkan diri dalam pengembangan ilmu pengetahuan dan teknologi. Pada akhirnya guru dapat menjalankan tugas-tugasnya (tugas professional, tugas manusiawi dan tugas kemasyarakatan) dengan baik, dan guru dapat meningkatkan kualitas pendidikan melalui kualitas profesinya.

Atas dasar itu, penulis menduga ada faktor yang memengaruhi kepuasan kerja. Pada dasarnya, guru di Sekolah Menengah Atas Negeri memiliki potensi untuk merasakan kepuasan dalam bekerja. Namun, kepuasan kerja guru tidak dapat dirasakan lebih baik karena dipengaruhi oleh faktor-faktor yang kompleks. Misalnya, faktor kepribadian, kecerdasan, usia, memainkan peran penting dalam menentukan kepuasan kerja guru (Gehlawat, 2012).

Kecerdasan emosional menjadi salah satu faktor yang memengaruhi kepuasan kerja guru di Sekolah Menengah Atas Negeri di Kota Kupang, karena kecerdasan emosional sebagai prediktor penting hasil organisasi untuk merasakan kepuasan kerja (Barsade dan Gibson dalam Shooshtarian, Ameli dan Amenilari, 2013). Sebagaimana yang dijelaskan oleh Goleman (dalam Kappagoda, 2011) bahwa kecerdasan emosional mempengaruhi efektifitas dan keberhasilan suatu organisasi. Hal ini didukung oleh Psilopanagioti, Anagnostopoulos, Mortou dan Niakas (2012) bahwa kecerdasan emosional berperan penting dalam menghasilkan kinerja dan kepuasan kerja. Menurut Goleman (dalam Luthans 2006) menyatakan kecerdasan emosional menjadi penting untuk mencapai kesuksesan dan keefektifan dalam dunia kerja (misalnya kesadaran diri, pengelolaan diri, motivasi diri, empati dan keterampilan sosial, juga dalam hal dengan relasi "people skill"). Selanjutnya aspek kecerdasan emosional, yakni penggunaan emosi, dan pengaturan emosi juga berhubungan dengan kepuasan kerja internal (Cekmecelioglu, Gunsel dan Ulutas, 2012), sebab individu yang dapat menggunakan dan mengontrol emosinya dengan baik, diindikasikan dapat merasakan kepuasannya dalam 
bekerja. Kecerdasan emosional tentunya dapat berhubungan dengan kepuasan kerja guru yang pada akhirnya dapat diharapkan sampai pada pencapaian tujuan pendidikan.

Terkait dengan hasil penelitian sebelumnya yakni penelitian dari Jeloudar dan Goodarzi (2012) pada guru-guru senior Sekolah Dasar di Iran, menunjukkan hasil yang positif dalam hubungan kecerdasan emosional dengan kepuasan kerja $(p<0,05)$. Sementara itu, Psilopanagioti et al. (2012) dari hasil penelitiannya ditemukan bahwa kecerdasan emosional signifikan dan berhubungan positif dengan kepuasan kerja $(p<0.01)$. Selanjutnya, penelitian dari Mehdi, Habib, Salah, Nahdid dan Gashtaseb (2012) pada pelatih sepakbola liga Premier, menemukan bahwa kecerdasan emosional mempunyai hubungan dengan kepuasan kerja, di mana hasil diperoleh dari pengukuran analisis korelasi diperoleh $r=0,40$ signifikan $0,018<0,05$. Juga penelitian dari Stewart (2008) menunjukkan bahwa ada hubungan positif kecerdasan emosional dengan kepuasan kerja pada 110 manager pelayanan makanan dari restoran franchise yang sama. Penelitian yang sama dari Afolabi, Awosola dan Omole (2010) yang menemukan kecerdasan emosional berhubungan signifikan $(p<0,1)$ dengan kepuasan kerja polisi di Nigeria. Cekmecelioglu (2012) menemukan adanya pengaruh signifikan dimensi penilaian emosional dengan nilai $p=0,000<0,05$ terhadap kepuasan kerja internal. Sebaliknya, kecerdasan emosional tidak ditemukan hubungannya dengan kepuasan kerja pada penelitian dari Farmer (2004) yang melakukan penelitiannya pada perawat di Utah yang mana dari nilai signifikansinya $0,456>0,05$.

Berangkat dari hasil-hasil penelitian sebelumnya tentunya penelitian hubungan kecerdasan emosional dengan kepuasan kerja guru telah dilakukan dalam bidang pendidikan namun yang diterapkan pada kasus dan konteks yang berbeda. Terjadinya perbedaan tersebut, mungkin disebabkan oleh adanya variasi tempat, situasi dan subjek penelitian. Penulis berasumsi bahwa apabila guru memiliki kecerdasan emosional yang tinggi, maka guru akan merasa puas dengan pekerjaannya. Sebaliknya, bila guru tidak memiliki kecerdasan emosional, maka guru merasa ketidakpuasan kerja yang ditunjukkan dengan perilaku negatif. Walaupun penelitian dengan subjek guru telah dilakukan pada penelitian-penelitian sebelumnya, namun penelitian ini memiliki perbedaan tempat penelitian. Dari sinilah penulis tertarik untuk melakukan penelitian terhadap guru-guru SMA Negeri di kota Kupang mengenai "Hubungan kecerdasan emosional dengan kepuasan kerja guru-guru SMA Negeri di Kota Kupang”.

Untuk mencari jawaban dan pembuktian, diajukan hipotesis yang mengatakan bahwa, ada hubungan signifikan antara kecerdasan emosional dan ketiga aspekya dengan kepuasan kerja guru-guru SMA Negeri di Kota Kupang. 


\section{METODE}

Subjek Penelitian

Populasi penelitian sebanyak 419 guru di SMA Negeri di Kota Kupang. Teknik pengambilan sampel yang digunakan adalah probability sampling, yakni teknik pengambilan sampel yang memberikan peluang yang sama bagi setiap (anggota) populasi untuk dipilih menjadi anggota sampel (Sugiyono, 2012). Untuk mendapat sampel Dari populasi 419 guru, diambil 106 guru yang bersertifikasi sebagai sampel dan menggunakan teknik probability sampling untuk mendapatkan sampel yang representatif atau yang sama porsinya dengan masing-masing jumlah guru SMA Negeri di Kota Kupang.

Alat Ukur Penelitian

Alat ukur ini berbentuk skala, di mana skala pengukuran kecerdasan emosional menggunakan skala Wong \& Law Emotional Intelligence Scale (WLEIS, 2002) yang terdiri atas 16 aitem sesuai dengan aitem yang dikutip dari Naseer dkk (2011). Tujuan alat ukur in iuntuk mengukur empat dimensi, yakni penilaian emosi pribadi (self-emotion appraisal), Penilaian emosi orang lain (emotion appraisal of others), penggunaan emosi (use of emotion), dan pengaturan emosi (regulation of emotion).

Skala Pengukuran kepuasan kerjanya disebut Overall Job Satisfaction yang dikembangkan oleh Dhespande (1996). Kepuasan kerja ini diukur berdasarkan lima dimensi, yaitu pekerjaan itu sendiri (work it self), gaji/upah (pay), promosi (promotion), pengawasan dan teman sekerja (co workers).

\section{HASIL DAN PEMBAHASAN}

Validitas dan reliabilitas masing-masing alat ukur pada taraf signifikansi 5\% adalah:

Kecerdasan Emosional

Nilai reliabilitas akhir dari butir yang terseleksi adalah sebesar 0.837 dengan kisaran 0.317 sampai 0.687. Dan karena nilai relibilitasnya tergolong tinggi dan baik, maka aitem-aitem nomor 6, 7 dan 9 diperbaiki pernyataan-pernyatannya dan dipakai dalam penelitian. Dan hasil uji reliabiltas penelitian diperoleh nilai coefisien alpha Cronbach's adalah 0.868 yang tergolong tinggi dan baik, dengan demikian semua aitem terbukti valid dan reliabel.

Kepuasan Kerja

Nilai reliabilitas akhir dari butir yang terseleksi adalah sebesar 0.832 dengan kisaran 0.335 sampai 0.618. Dan terdapat 2 aitem yang gugur, yaitu aitem 9 dan 10. . Namun aitem-aitem ini 
diperbaiki dan dipakai dalam penelitian. Hasil uji reliabilitas penelitian terdapat 1 aitem yang tidak dapat dipertahankan. Perhitungan validitas diperoleh 1 aitem gugur sehingga terdapat 18 aitem valid dengan kisaran 0.354 sampai 0.673 dan Coefisien alpha Cronbach's 0.878 , yang tergolong tinggi dan baik, dengan demikian semua aitem terbukti valid dan reliabel.

Data penelitian kuantitatif ini akan dianalisis dengan metode statistik korelasi berganda Untuk kepentingan ini, analisis difokuskan pada hipotesis: Ada hubungan signifikan antara kecerdasan emosional dan ketiga aspeknya dengan kepuasan kerja guru SMA di kota Kupang. Hasil Uji Korelasi Berganda

Hasil pengujian hipotesis menunjukkan bahwa ada hubungan antara kecerdasan emosional dan ketiga aspeknya, dengan kepuasan kerja guru SMA Negeri di Kota Kupang dapat diterima. Hal tersebut dapat dilihat pada Tabel 1

Tabel 1

Hasil uji korelasi pearson kecerdasan emosional dan ketiga aspek kecerdasan emosional dengan kepuasan kerja

\begin{tabular}{|c|c|c|c|c|c|c|}
\hline \multicolumn{7}{|l|}{ Correlations } \\
\hline & & $\begin{array}{l}\text { Kecerdasan_E } \\
\text { mosional }\end{array}$ & $\begin{array}{l}\text { Penilaian_- } \\
\text { dan_- } \\
\text { Ekspresi }\end{array}$ & $\begin{array}{l}\text { Penggunaan } \\
\text { Emosi }\end{array}$ & $\begin{array}{l}\text { Pengaturan } \\
\text { Emosi }\end{array}$ & $\begin{array}{l}\text { Kepuasan } \\
\text { kerja }\end{array}$ \\
\hline \multirow[t]{3}{*}{$\begin{array}{l}\text { Kecerdasan } \\
\text { Emosional }\end{array}$} & $\begin{array}{l}\text { Pearson } \\
\text { Correlation }\end{array}$ & 1 & $.885^{* *}$ & $.779^{* *}$ & $.763^{* *}$ & $.622^{* *}$ \\
\hline & Sig. (2-tailed) & & .000 & .000 & .000 & .000 \\
\hline & $\mathrm{N}$ & 106 & 106 & 106 & 106 & 106 \\
\hline \multirow[t]{3}{*}{$\begin{array}{l}\text { Penilaian_- } \\
\text { dan_Ekspresi }\end{array}$} & $\begin{array}{l}\text { Pearson } \\
\text { Correlation } \\
\end{array}$ & $.885^{* *}$ & 1 & $.508^{* *}$ & $.497^{* *}$ & $.564^{* *}$ \\
\hline & Sig. (2-tailed) & .000 & & .000 & .000 & .000 \\
\hline & $\mathrm{N}$ & 106 & 106 & 106 & 106 & 106 \\
\hline \multirow[t]{3}{*}{$\begin{array}{l}\text { Penggunaan_- } \\
\text { Emosi }\end{array}$} & $\begin{array}{l}\text { Pearson } \\
\text { Correlation }\end{array}$ & $.779^{* *}$ & $.508^{* *}$ & 1 & $.487^{* *}$ & $.537^{* *}$ \\
\hline & Sig. (2-tailed) & .000 & .000 & & .000 & .000 \\
\hline & $\mathrm{N}$ & 106 & 106 & 106 & 106 & 106 \\
\hline \multirow[t]{3}{*}{$\begin{array}{l}\text { Pengaturan } \\
\text { Emosi }\end{array}$} & $\begin{array}{l}\text { Pearson } \\
\text { Correlation } \\
\end{array}$ & $.763^{* *}$ & $.497^{* *}$ & $.487^{* *}$ & 1 & $.396^{* *}$ \\
\hline & Sig. (2-tailed) & .000 & .000 & .000 & & .000 \\
\hline & $\mathrm{N}$ & 106 & 106 & 106 & 106 & 106 \\
\hline \multirow[t]{3}{*}{$\begin{array}{l}\text { Kepuasan_ } \\
\text { kerja }\end{array}$} & $\begin{array}{l}\text { Pearson } \\
\text { Correlation }\end{array}$ & $.622^{* *}$ & $.564^{* *}$ & $.537^{* *}$ & $.396^{* *}$ & 1 \\
\hline & Sig. (2-tailed) & .000 & .000 & .000 & .000 & \\
\hline & $\mathrm{N}$ & 106 & 106 & 106 & 106 & 106 \\
\hline
\end{tabular}


Berdasarkan tabel di atas dapat diketahui bahwa nilai $p$ value kecerdasan emosional dengan kepuasan kerja $<\alpha=0,000<0,05, p$ value penilaian dan ekspresi (diri sendiri dan orang lain) dengan kepuasan kerja $<\alpha=0,000<0,05, p$ value penggunaan emosi dengan kepuasan kerja $<\alpha=0,000<0,05$ dan $p$ value pengaturan emosi dengan komitmen organisasi $<\alpha=0,000$. Selanjutnya nilai korelasi Pearson (r) dari kecerdasan emosional sebesar $\mathrm{r}=0,622$, dan karena nilai korelasi berada pada range 0,599-0,799, maka terdapat hubungan yang kuat antara kecerdasan emosional dengan kepuasan kerja dengan arah positif. Aspek penilaian dan ekspresi (diri sendiri dan orang lain), dengan kepuasan kerja sebesar $r=0,564$ dan karena besarnya nilai korelasi $\mathrm{r}$ berada pada range 0,340-0,599, maka terdapat hubungan yang sedang antara dimensi penilaian dan ekspresi (diri sendiri dan orang lain), dengan kepuasan kerja dengan arah positif. Kemudian nilai korelasi Pearson dari aspek penggunaan emosi dengan kepuasan kerja sebesar $\mathrm{r}=0,537$, dan karena besarnya nilai korelasi $\mathrm{r}$ berada pada range 0,340-0,599, maka terdapat hubungan sedang antara dimensi penggunaan emosi dengan kepuasan kerja dan arahnya positif. Dan aspek ketiga yakni pengaturan emosi nilai korelasi Pearsonnya sebesar $\mathrm{r}=0,396$, dan karena besarnya korelasi berada pada range 0,200-0,399 maka terdapat hubungan yang rendah antara dimensi pengaturan emosi dengan kepuasan kerja dan arahnya positif. Semakin tinggi penilaian dan ekspresi (diri sendiri dan orang lain), maka akan diikuti semakin tinggi kepuasan kerja. Selanjutnya semakin tinggi penggunaan emosi dan pengaturan emosi, maka akan diikuti semakin tinggi kepuasan kerja. Dengan demikian terdapat hubungan signifikan antara penilaian dan ekspresi (diri sendiri dan orang lain), penggunaan emosi dan pengaturan emosi dengan kepuasan kerja.

Berdasarkan hasil pengukuran analisis data di atas, dengan menggunakan uji korelasi multivariat, maka hipotesis diterima dengan penjelasan sebagai berikut: Kecerdasan emosional merupakan salah satu variabel yang memiliki hubungan positif signifikan dengan kepuasan kerja guru SMA Negeri di Kota Kupang. Hal ini dapat ditunjukkan pada Tabel 1 di mana nilai korelasi pearson sebesar 0,622 dan terdapat hubungan yang kuat. Dalam hal ini guru-guru SMA Negeri di Kota Kupang telah mempunyai kecerdasan emosional yang kuat dan menyebabkan mereka mengalami kepuasan dalam bekerja.

Adanya hubungan yang signifikan menggambarkan bahwa guru SMA Negeri di Kota Kupang memiliki kecerdasan emosional yang kuat dan memainkan peran besar dalam membentuk individu untuk mengalami kepuasan kerja. Hal ini sejalan dengan apa yang dikemukakan oleh Goleman (dalam Murphy, 2006) bahwa kecerdasan emosional memegang peran terhadap 
pentingnya kualitas hidup manusia, misalnya hubungan interpersonal, kepuasan hidup, dan keberhasilan akademis. Ini berarti kecerdasan emosional penting bagi seorang guru sebab bila guru tidak mampu mengelola emosinya dengan baik dan berperilaku negatif, maka akan mempengaruhi efektifitas dalam pengajarannya sehingga pada akhirnya guru mengalami kemunduran dalam pekerjaannya dan berakibat merusak kepuasan kerjanya sendiri. Hal ini mungkin dapat dilihat dari bagaimana guru SMA Negeri di Kota Kupang dapat mengetahui emosi yang dirasakan, dan dengan semangat terdorong untuk melakukan tugasnya dengan baik serta dapat menetralisir emosi negatif terhadap masalah yang dihadapi terkait dengan proses belajar mengajar di sekolah dan membuat mereka mengalami kepuasan kerja. Ini menggambarkan bahwa individu yang memiliki kecerdasan emosional memiliki hubungan dengan kepuasannya dalam bekerja.

Hasil tersebut sesuai dengan hasil-hasil penelitian yang dilakukan oleh Jeloudar dan Goodarzi (2012), Mehdi et al. (2012), Stewart (2008), Afolabi et al. (2010), Mousavi et al. (2012), Craig (2008), Agbolou (2011), Nezad dan Bahramzade (2013), Seyal dan Afzaal (2013), Cotzer (2013), Salim et al. (2012), Australia Industrial \& Organisational Psychology Conference (2003), Ealias (2012), Herman (2012), Fatima et al. (2010), Ghoniem et al. (2011) yang menujukkan hasil adanya hubungan kecerdasan emosional dengan kepuasan kerja. Sebaliknya, kecerdasan emosional tidak ditemukan hubungannya dengan kepuasan kerja pada penelitian dari Farmer (2004) yang melakukan penelitiannya pada perawat di Utah yang mana dari nilai signifikansinya $0,456>0,05$.

Kecerdasan emosional tersebut tergambar dalam tiga aspek seperti yang dikemukakan oleh Wong dan Law yang dikutip oleh Naseer et al. (2011) yaitu penilaian dan ekspresi (diri sendiri dan orang lain), penggunaan emosi dan pengaturan emosi. Dari beberapa aspek kecerdasan emosional tersebut terlihat pada Tabel 4.10.

Aspek penilaian dan ekspresi (diri sendiri dan orang lain) memiliki hubungan signifikan positif dengan kepuasan kerja, dengan nilai korelasi pearson sebesar 0,564 dan nilai $p<\alpha(0,000<$ 0,05). Besarnya hubungan dari aspek penilaian dan ekspresi (diri sendiri dan orang lain) ini termasuk dalam range sedang, ini mungkin disebabkan karena pada umumnya guru SMA Negeri di Kota Kupang cukup dapat menilai dan mengekspresikan emosi mereka dan sejauh mana emosi positif diungkap secara verbal dan non verbal untuk terciptanya kerja yang lebih efektif dan efisien yang pada akhirnya membuat guru mengalami kepuasan kerja.

Hasil tersebut didukung dengan penelitian dari Cekmecelioglu et al. (2012) di mana dimensi penilaian emosional signifikan berpengaruh terhadap kepuasan kerja internal yang ditunjukkan 
dengan nilai $p=0,000<0,05$ dan berbeda atau tidak signifikan berpengaruh terhadap kepuasan kerja external $(p=0,108>0,05)$. Perbedaan hasil ini sama dengan penelitian dari Orhan dan Dincer (n.d) di mana dalam penelitiannya ditemukan dimensi penilaian dan ekspresi emosi (diri sendiri dan orang lain) tidak mempunyai hubungan signifikan dengan kepuasan kerja $(\mathrm{p}=0,666>0,05)$.

Aspek penggunaan emosi memiliki hubungan signifikan positif dengan kepuasan kerja. Nilai $p<\alpha(0,000<0,05)$ dan nilai korelasi Pearson (r) sebesar 0,537 dan tergolong sedang. Argumentasi penulis, adanya hubungan aspek penggunaan emosi dengan kepuasan kerja menunjukkan adanya penggunaan emosi guru yang cukup stabil dalam melaksanakan tugas pengajarannya membuat guru termotivasi dalam bekerja lebih baik dan kondisi ini membuat guru mengalami kepuasan kerja. Penggunaan emosi positif dari guru SMA Negeri di Kota Kupang, misalnya ditunjukkan dengan sikap positif yang tetap mengerjakan tugas-tugas saat ada kesulitan/masalah (baik itu terkait dengan siswa maupun sesama guru), tetap meyakini bahwa diri sendiri adalah seorang guru yang berkompeten yang ditunjukkan melalui kualitas kerja, dan dapat mencapai tujuan yang telah ditetapkan dalam mengajar dan akhirnya mengalami kepuasan kerja. Terkait dengan penelitian sebelumnya, hasil ini berbeda pada hasil penelitian Orhan dan Dincer (n.d) di mana dimensi penggunaan emosi tidak mempunyai hubungan signifikan dengan kepuasan kerja $(p=0,024>0,05)$.

Aspek pengaturan emosi memiliki hubungan signifikan positif dengan kepuasan kerja. Nilai $p$ $<\alpha(0,000<0,05)$ dan nilai korelasi Pearson sebesar 0,396 dan tergolong rendah. Adanya hubungan aspek pengaturan emosi yang rendah terkait dengan guru yang kurang dapat mengatur emosinya dengan baik sehingga menggangu pelaksanaan tugas dan tanggungjawab pengajaran yang membuat kepuasan kerjanya juga menurun. Hal tersebut terjadi mungkin ketika menghadapi kesulitan dan belum dapat mengontrol serta mengendalikan emosi dengan baik saat ada kemarahan (mungkin marah terhadap siswa saat mereka tidak mengerjakan tugas atau marah dengan situasi dan kondisi sekolah yang tidak mendukung suasana kerja di sekolah).

Hal ini sesuai dengan teori Salovey dan Mayer (dalam Berrocal dan Extremera, 2006) bahwa perlunya regulasi emosional mengacu pada kemampuan terbuka terhadap perasaan dan untuk memantau serta mengatur emosi seseorang dan lainya dalam upaya pertumbuhan pribadi, selanjutnya dapat mengalami kepuasan kerja. Hasil ini didukung oleh penelitian dari Orhan dan Dincer (n.d) yang mana dimensi pengaturan emosional mempunyai hubungan signifikan dengan kepuasan kerja $(\mathrm{p}<0,05)$, namun berbeda pada hasil penelitian dari Cekmecelioglu et 
al. (2012) di mana aspek pengaturan emosional tidak signifikan berpengaruh terhadap kepuasan kerja internal dengan nilai $p=0,55>0,05$ dan juga tidak signifikan berpengaruh terhadap kepuasan kerja external dengan nilai $p=0,228>0,05$.

\section{SIMPULAN}

Dengan demikian guru-guru di Sekolah Menengah Atas di Kota Kupang yang memiliki kecerdasan emosional adalah yang memiliki kemampuan sosial yang baik serta mampu memahami emosi sehingga dengan demikian akan lebih mampu mentolelir frustasi, mengetahui perencanaan yang lebih baik di masa depan untuk meningkatkan kepuasan kerja.

Saran

Bagi Guru

Guru harus dapat memaksimalkan pengembangan kecerdasan emosionalnya, misalnya melalui pertemuan untuk diskusi bersama dengan sesama guru untuk bertukar pendapat dan memberikan masukkan-masukkan yang positif dalam meningkatkan kecerdasan emosional untuk peningkatan produktifitas pendidikan di sekolah, sehingga kepuasan kerja dapat dirasakan.

Guru harus meningkatkan kesadaran dalam diri sendiri mengenai pemahaman terhadap emosinya, yakni kemampuan untuk memahami orang lain lewat emosi yang diungkap secara verbal maupun non verbal, sehingga dapat mengembangkan empati juga terhadap orang lain, sehingga dapat merasakan kepuasannya dalam kerja.

Guru dapat meningkatkan penggunaan emosinya dengan peningkatan ketekunan melaksanakan tugas-tugas yang sulit, meningkatkan emosi positif bila berhadapan dengan murid yang membangkang sehingga dapat bertindak dengan baik karena emosi yang positif dapat lebih memahami orang lain juga dalam proses pengambilan keputusan terkait dengan tugas sebagai guru, dan akhirnya guru dapat mengalami kepuasan kerja.

Guru dapat meningkatkan pengaturan emosinya, misalnya dapat mengendalikan emosi dalam menghadapi kesulitan terkait tugas pengajaran, dan dapat menetralisir emosi dengan cepat saat sedang marah sehingga guru dapat merasa kepuasan kerja dapat tercapai

Bagi Penelitian selanjutnya

Untuk peneliti selanjutnya mungkin dapat menambahkan variabel lain yang memiliki hubungan dengan kepuasan kerja seperti faktor kepemimpinan, kepribadian, dan lain sebagainya. 
Peneliti selanjutnya mungkin dapat memperluas area penelitian dengan menambah Sekolahsekolah Menengah Atas lain yang tidak saja berada pada wilayah kota tapi bisa untuk wilayah kabupaten atau propinsi.

Peneliti selanjutnya mungkin dapat memperluas area penelitian ke Sekolah-sekolah Menengah Atas kejuruan dan swasta.

Peneliti selanjutnya juga mungkin dapat memperluas area penelitian ke jenjang pendidikan lainnya misalnya, Sekolah Dasar, Sekolah Menengah Pertama dan Perguruan Tinggi.

\section{DAFTAR PUSTAKA}

Afolabi, O.A., Awosola, R. K., \& Omole, S. O. (2010). Influence of emotional intelligence and gender on job performance and jobsatisfaction among Nigerian Policemen. Current Research Journal of Social Sciences, 2 (3), 147-157

Agbolou, K. (2011). Intelligence and job satisfaction: A correlation analysis of a retail organizational. ProQuest Dissertations and Theses. 172 pages. University of Phoenix Retrieved

Agyekum, N.N.A., Suapim, R.H., \& Peprah, S.O. (2013). Determinants of Job Satisfaction among Ghanaian Teachers . Journal of Education and Practice, 4(3), 43-50

Australia Industrial \& Organisational Psyhology Conference. (2003). Assesing the relationship between workplace emotional intelligence, job satisfaction and organizational commitment. Paper accepted for presentation at the $5^{\text {th }}$ Australia Industrial \& Organisational Psychology Conference.

Berrocal, P. F., \& Extremera, N. (2006). Emotional intelligence: A theoretical and empirical review of its first 15 years of history. Psicothema 2006,18, 7-12.

Cekmecelioglu, H, G., Gunsel, A., \& Ulutas, T. (2012). Effects of emotional intelligence on job satisfaction: An empirical study on call center employees. Procedia-Social Behavioral Sciences 58(2012), 363-369

Chao, K. L. (2011). Relationship among job characteristics, job satisfaction, and turnover intention within kindergartens: An empirical study in Taiwan. Journal early childhood education research, $l 3,1-40$

Coetzer, W.C. (2013). The relationship between emotional intelligence and job satisfaction amongst westcol fet lecturers. (Minor Disertation). University of Johannesburg. 
Craig, J, B. (2008)."The relationship between the emotional

intelligence of the

principal and teacher job satisfaction" (January 1, 2008). Dissertations available from ProQuest. Paper AAI3310476.

Dahlan, D. tt. Analisis Fakor-faktor yang mempengaruhi Kepuasan Kerja Guru (Studi Deskriptif Analitik pada SMA Negeri Se Kabupaten Buleleng). Retrievedfromhttp://file.upi.edu/Direktori/FPEB/PRODI._EKONOMI_DAN_KOPER ASI/195712051982031DADANG_DAHLAN/Hasil_Penelitian_3.pdf

Dellasera, Q. (2013, Mey 03). Kualitas pendidikan Indonesia (refleksi 2 mey). Kompasiana. Retrieved from http://edukasi.kompasiana.com/2013/05/03/kualitas-pendidikanindonesia-refleksi-2-mei-552591.html

Deshpande., S.P. (1996). The impact of ethical climate types on facets of satisfaction: an empirical investigation. Journal of Business Ethics 15, 655-660,

Ealias, A. (2012). Emotional intelligence and job satisfaction: A correlational study. The International Journal's Research Journal of Commerce \& Behavioral Science, 01, (4), $37-42$

Farmer, S. (2004). The relationship of emotional intelligence to burnout and job satisfaction among nurses in early nursing practice. Disertasi College of Nursing: Universitas Utah.

Fatima, A., Imran, R., \& Zaheer, A. (2010). Emotional intelligence and job satisfaction mediated by transformational leadership. World Applied Sciences Journal. 10 (6),612620

Gehlawat, M. (2012). Organizational commitment in relation to job satisfaction and work motivation of secondary school teachers working in different types of schools. Thesis for the degree of Doctor of Philosophy in education. Rohtak: Maharshi Dayanand University.

Ghoniem, A., Elkhouli, S., Mohsen, G., \& Ibrahim, M. (2011). Impact of emotional intelligence and gender on job satisfaction among Egyptian government sector employees. Current Research Journal of Social Science, 3(1), 22-27

Hanaysha, J.R.M., Khalid,K., Mat, N.K.N., Sarassina, F., Rahman, M. Y. B. A., \& Zakaria, A.S.B. (2012). Transformationaal leadership and job satisfaction. American Journal of Economics June 2012, Special Issue: 145-148

Herman, C. (2012). Developing emotional intelligence for increased work engagement, organizational commitment, and satisfaction with work life. Tesis Presented in partial 
fulfillment of the requirements for the degree of masters of commerce (industrial psychology) at the University of Stellenbosch. Retrieved from http://scholar.sun.ac.za/bitstream/handle/10019.1/80133/herman_developing_2013.pd f?sequence $=1$

Hutagaol, NT. (2012). Kepuasan Kerja Guru. Unimed

Jeloudar, A. Y \& Goodarzi, F, L. (2012). Teachers' emotional intelligence and its relationship with job satisfaction. Journal advances in education, 1 (1), 4-9

Kappagoda. U. W. M. R. S. (2001). The relationship between principals' emotional intelligence and teacher's job satisfaction: A case of national schools in Sri Lanka. Journal faculty of Commerce and Management Studies ICBI 2011. Retrieved from http://repository.kln.ac.lk/id/eprint/50

Luthans. F. (2006). Perilaku Organisasi. Yogyakarta: Andi

Malik, M E., Nawab, S., Naeem, B., \& Danish, R. Q., (2010). Job satisfaction and organizational commitment of university teachers in public sector of Pakistan. International Journal of Business and Management, 5, (6), 17-26

Mehdi, M., Habib, H., Salah, N., Nahdid, J., \& Gashtaseb, A. (2012). The relationship between emotional intelligence and job satisfaction among coaches in Premier Under-20 Footbal League. International Journal of Academic Research and Social Science. 2(5),73-83

Michaelowa, K., \& Wittmann, E. (2002). Teacher Job Satisfaction, student achievement, and the cost of primary education in Francophone Sub-Saharan Africa. Hamburgisches Welt - Wirtschafts - Archiv Discussion Paper, 1-34.

Munandar, A. S.. (2006). Psikologi Industri dan Organisasi. Jakarta: UI Press

Murphy, K, T. (2006). The retaltionship between emotional intelligenge and satisfaction with life after controllong for sel-esteem, depression, and locus of control among community college students. Disertation. Department of higher education college of education: University of South Florida

Mousavi, S. H., Yarmohammadi, S., Nosrat, A. B., \& Tarasi, Z. (2012). The relationship between emotionall intelligence and job satisfaction of physical education teachers. Annals of Biological Research, 3(1),736-745

Napitupulu, E.L. (2012 November 08). Guru laporkan masalah pembayaran tunjangan profesi. Kompas.com..

Napitupulu, E. L. (2013, Mey 17). Pembayaran tunjangan guru tak sesuai SK. Kompas.com.. 
Naseer, Z., Chisthi, S, U, H., Rahman, F., \& Jumani, N, B. (2011). Impact of emotional intelligence on team performance in higher education institutes. International Online Journal of Educational Sciences, 3(1), 30-46

Nezad, F, S., \& Bahramzade, M, R. (2013). Relationship between emotional intelligence and job satisfaction. Europian Online Journal of Natural and Social Sciences, 2(3), 979984.

Ngimbudzi, F.W. (2009). Job SATISFACTION Among Secondary School Teachers In Tanzania: The Case Of Njombe District. Master's Thesis In Education Spring Department of Educational Leadership: University of Jyvaskyla

Pidarta. M. (2000). Landasan Kependidikan; Simulus ilmu bercorak Indonesia. Jakarta: Rineka Cipta

Psilopanagioti, A., Anagnostopoulos, F., Mortou, E., \& Niakas, D. (2012). Emotional intelligence, emotional labor, and job satisfaction among physicians in Greece. BMC Health Services Research 2012, 12-463.

Rochaety, E., Rahayuningsih, P., \& Yanti, P.G. (2006).Sistem Informasi Manajemen Pendidikan.. Jakarta: PT. Bumi Aksara

Salim, S. S. S., Nasir, R., Arip, M. A. S. M., \& Mustafa, M. B. (2012). The role of emotional intelligence on job satisfaction among school teachers. Journal of Social Science, 7 (1), 125-129

Schneider, M. (2003). Linking School Facility Conditions to Teacher Satisfaction and Success. National Clearinghouse for Educational Facilities, (August)

Sisask, M., Apter, A., Balazs, J., Balint, M., Bobes , J., Brunner, R., Wasserman, D. (2014). Teacher Satisfaction with school and Psychologycal well-being affects their readiness to help children with mental health problems. Health Education Journal, 73 (4), 382393

Seyal, A, H. \& Afzaal, T. (2013). An investigation of relationship among emotional intelligence, organizational commitment and job satisfaction: Evidence from academics in Brunei Darussalam. International Business Research, 6(3), 217-228.

Shooshtarian, Z., Ameli, F \& Aminilari, M. (2013). The effect of labor's emotional intelligence on their job satisfaction, job performance and commitment. Irannian journal of Management Studies (IJMS), 6(1), 29-45. 
Stewart, G.L. (2008). The relationship of emotional intelligence to job satisfaction anf organizational commitment. Disertasion: Doctor of Philosophy. Regent University: United

Sugiyono. (2012). Statistik untuk penelitian. Bandung: Alfabeta

UPT Pengembangan Pendidikan Nonformal dan Formal. (2009, November 4). Menemukan Masalah Pendidikan NTT.

Wijono, S. (2012). Psikologi Industri dan Organisasi. Jakarta: Kencana Prenada Media Group Zembylas.M \& Papanastasiou. E. (2004). Job Satisfaction among school teachers in Cyprus. Journal of Educational Administration 42 (3), 357-374.. 